Jurij Snoj

\title{
Music Fragments from Slovenia: Towards a Reconstruction of the Medieval Plainchant Manuscript Production
}

\begin{abstract}
The article presents the results of a systematic search for fragments of medieval music manuscripts in Slovenian libraries. The material found is analysed in respect of contents (types of manuscripts), notation, and date of the origin. Conjectures are made about the time of the destruction of the manuscripts to which the fragments belonged, as well as concerning the question of which fragments belonged to manuscripts that were actually in use in the country and which have just casually arrived in their present locations. Some more interesting fragments are described in detail.
\end{abstract}

A few decades ago, a systematic search for medieval music manuscripts and fragments was carried out in the libraries and archives of Ljubljana, Slovenia. The aim was to collect and describe all documents written before the Tridentine reforms that included some kind of music notation, be they complete or mutilated music manuscripts, fragments of destroyed music manuscripts or just small music entries in otherwise non-music manuscripts. ${ }^{1}$ In conjunction with the search, a database was compiled, containing all the most important information about the sources found. ${ }^{2}$ At present, the work is in progress and there are still some important libraries or archives outside Ljubljana that need to be thoroughly

1 The following institutions were examined: SI-Lna (Nadškofijski arhiv Ljubljana / Archiepiscopal Archives of Ljubljana), SI-Ln (Narodna in univerzitetna knjižnica / National and University Library), SI-Lz (Zgodovinski arhiv Ljubljana / Historical Archives Ljubljana), SI-Las (Arhiv Republike Slovenije / Archives of the Republic of Slovenia), Uršulinski samostan Ljubljana / Ursuline Convent Ljubljana, SI-Lsa (Biblioteka SAZU / The Library of the Academy of Sciences and Arts), SI-Lsk (Semeniška knjižnica / The Seminary Library), SI-Lf (Frančiškanski samostan Ljubljana - Center / The Franciscan Monastery Ljubljana), Knjižnica Narodnega muzeja / The Library of the National Museum. Some other areas across Slovenia were explored in a similar way on a later campaign.

2 Published as a catalogue in the following collection of essays, Snoj 2018, 353-463.

๖ Open Access. ( 2020 Jurij Snoj, published by De Gruyter. (cc)BY-NC-ND This work is licensed under the Creative Commons Attribution-NonCommercial-NoDerivatives 4.0 International License.

https://doi.org/10.1515/9783110717884-005 
surveyed for the presence of medieval music sources. The whole undertaking may be compared to other similar and sometimes much more extensive projects carried out elsewhere at the same time. ${ }^{3}$

The typology of medieval music manuscript sources that have emerged is varied. Even in a relatively small area such as Slovenia, it is possible to find different classes of codices, or fragments thereof, that are of relevance for the study of the musical life in the Middle Ages: plainchant manuscripts of various types, primarily intended for singers; other liturgical manuscripts not intended for musical performance yet occasionally containing notated chants (e.g. missals, psalters, pontificals); non-notated liturgical manuscripts where individual chants were only later provided with musical notation; music records and marginalia in non-musical codices which seem to have no connection with the contents of the manuscripts; scraps of polyphony; music treatises and printed chant books either complete or fragmentary. Such typological diversity implies, at least to some degree, a variety of functions that music and singing had in the daily life of medieval liturgical communities. Not surprisingly, the great majority of the sources found represent fragments of destroyed music codices.

\section{A statistical overview}

I will start by presenting a statistical overview of the whole collection of fragments. ${ }^{4}$ At the current stage of research, in Slovenia there are 618 complete and incomplete folios and 158 tiny parchment or paper scraps containing some kind of music notation, possibly coming from 222 different original manuscripts. Among these, the most numerous by far are liturgical manuscripts containing plainchant, while others include a few fragments with polyphonic music and a fragment of a theoretical treatise.

3 Such as Szendrei 2002; Brunius 2005; Veselovská 2002; Veselovská 2006. There are several reports on similar projects in the proceedings quoted above as well as in the following ones Brownrigg/Smith 2000; Hiley 2004. Collections of medieval music fragments can also be found in a number of different websites, e.g. Slovakian Early Music database <http://cantus.sk>, Medieval Manuscripts and Parchment Fragments from Finland <https://pro.europeana.eu/data/ medieval-manuscripts-and-parchment-fragments-from-finland>, Musikalische Quellen des Mittelalters in $\operatorname{der} O ̈ N B<$ http://www.cantusplanus.at/de-at>, etc.

4 The overview is based on the printed catalogue of medieval music sources in Slovenian libraries Snoj 2018. 
The difference between the number of folios found and the number of manuscripts they belonged to suggests that many of the reconstructed fragments consist just of a small number of folios. Table 1 shows the number of the preserved folios of 215 fragments of plainchant manuscripts. The most numerous are fragments consisting of just one or two complete or almost-complete folios, constituting more than half of the whole collection. The number of destroyed liturgical manuscripts surpasses the needs of the churches that existed in the territory of Slovenia, suggesting that they come from a wider central-European area, and not just from Slovenian locations.

Table 1: The extent of the plainchant fragments.

\begin{tabular}{|c|c|}
\hline No. of fragments & No. of folios \\
\hline 118 & 1 \\
\hline 52 & 2 \\
\hline 5 & 3 \\
\hline 13 & 4 \\
\hline 2 & 5 \\
\hline 6 & 6 \\
\hline 1 & 7 \\
\hline 4 & 8 \\
\hline 2 & 9 \\
\hline 3 & 10 \\
\hline 1 & 11 \\
\hline 1 & 14 \\
\hline 1 & 16 \\
\hline 1 & 21 \\
\hline 1 & 22 \\
\hline 1 & 24 \\
\hline 1 & 28 \\
\hline 1 & 35 \\
\hline 1 & 39 \\
\hline Total: & 265 \\
\hline
\end{tabular}

The most extensive group, that of liturgical plainchant manuscripts, requires further distinguishment. Firstly, the group can be divided according to the type of musical notation and, thus, also according to an approximate date of 
production (Table 2). The most numerous are fragments in German 'GothicMessine' notation, followed by fragments in square notation, and those in German adiastematic neumes, while other types of notation are less represented.

Table 2: The notation of plainchant fragments. ${ }^{5}$

\begin{tabular}{lll}
\hline Notation & No. of folios & No. of manuscripts \\
\hline German adiastematic & $50,51^{\star}, 46^{\star \star}$ & 30,4 \\
Other adiastematic & $1,5^{\star}, 10^{\star \star}$ & 4,1 \\
German stave & $2,6^{\star}$ & 5 \\
Cistercian & $2,2^{\star}$ & 2 \\
Italian stave & $6,2^{\star}, 1^{\star \star}$ & 3 \\
Gothic Messine & $218,138^{\star}, 40^{\star \star}$ & 88 \\
Hufnagelschrift & $5,6^{\star}$ & 8 \\
Other Gothic & $11,7^{\star}, 34^{\star \star}$ & 22,3 \\
Square & $48,46^{\star}, 26^{\star \star}$ & 44,1 \\
\hline Total: & $343,263^{\star}, 157^{\star \star}$ & 215 \\
\hline
\end{tabular}

Strictly speaking, however, every fragment calls for a detailed analysis of its notation. Some fragments were too small to allow for an identification of the notation. Furthermore, the identification of notational types by following commonly accepted categories may not always lead to an adequately exact definition of the notation of a particular fragment. This is due to a multitude of hybrid types of music scripts, as well as the different practices of writing music. By analysing the notation of fragments in German adiastematic neumes, for example, it is possible to observe that they do not function in a fully systematic, and internally coherent way. Besides those graphical differences between particular elements of the script that do not affect the musical meaning (e. g. the graphical form of the virga, the axis of the script, etc.), discrepancies are evident in the composition of the signs and in their meaning. For instance, in one fragment (Fig. 1) there are many quilisma signs but no scandicus signs: from the comparison of the melodic

5 In the third column, the second number refers to fragments of liturgical manuscripts with occasional musical entries that do not appear to be an essential part of their contents, e.g. breviaries and lectionaries with later music insertions. Incomplete folios and scraps are marked respectively with one asterisk, and two. 
version with other sources, it becomes clear how in this fragment the quilisma stands for the ordinary scandicus. ${ }^{6}$

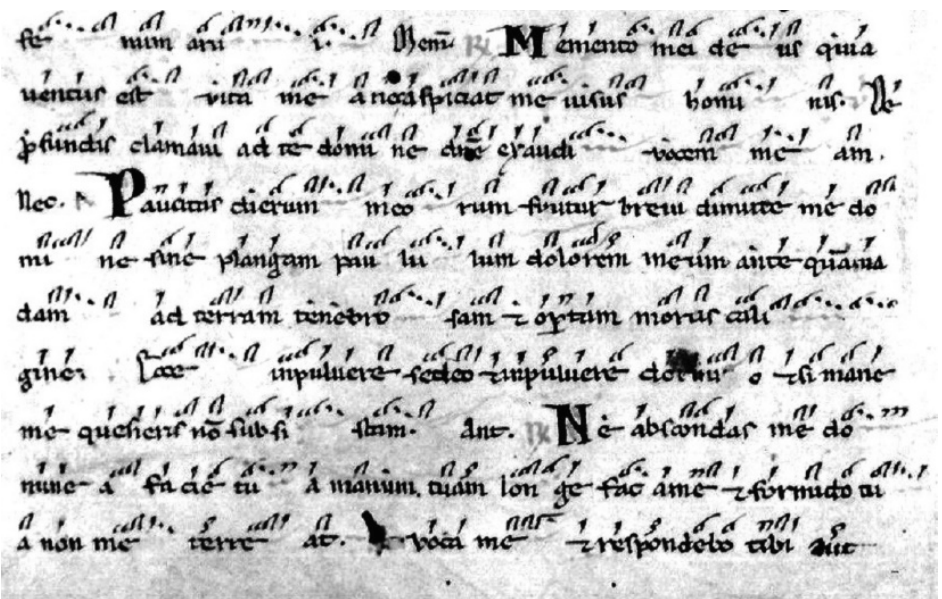

Fig. 1: Novo mesto, Franciscan Monastery, inv. n. 7202 (fragment in the binding), Historia Job; (c) Novo mesto, Franciscan Monastery.

Unlike fragments featuring German neumes, the notation of those in German 'Gothic-Messine' appears to be more homogeneous. 'The essential characteristics of this notation are (cf. Figs 2 and 5): (1) the punctum is normally used as the sign for a single note, while the virga is employed for this function only exceptionally; (2) the clivis (or flexa) is represented by two joined puncta, rather than with the graphic element of the upside-down U, which appears only in various torculi; (3) the compound signs are composed of both punctum and virga, the latter standing normally for the highest note in the group, giving the notation its characteristic appearance. All eighty-eight fragments featuring this type of notation match such criteria, with the exception of some fragments in which the virga is used occasionally as a sign for a single note. German 'Gothic-Messine' notation, which seems to have been the most usual way of writing music in South German areas during the late Middle Ages, should be distinguished both from other types of

6 The fragment is no. 2.9 in Snoj 2018.

7 There is no commonly accepted term for such type of notation. Bruno Stäblein refers to this notation as 'Metzer Notation der III. Epoche'; Stäblein 1975, 67-68. The term 'German Messine Gothic' is taken from Hiley/Szendrei 2001. 
Gothic notation, like the so-called 'Hufnagel' which employs the virga as a standard sign for a single note, and the shape of upside-down $U$ for the clivis, as well as from Eastern types of Gothic notation that avoid instead the use of the virga, be it as a sign for a single note or in compound signs.

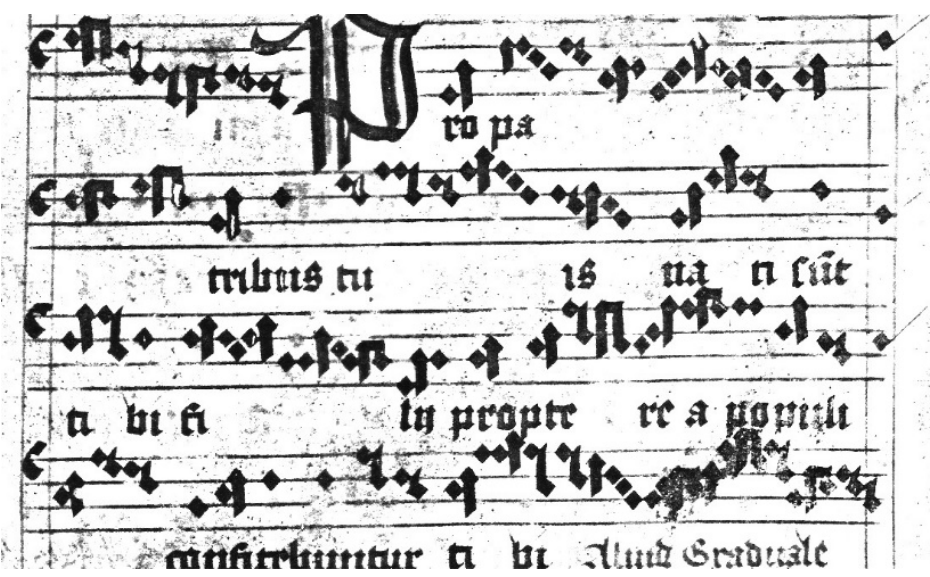

Fig. 2: SI-Lz, LJU/0338, Maculatures II (2), Folder 8, Gradual Constitues eos; @ Ljubljana, Historical Archives.

From this initial survey, it is possible to conclude that the picture of notational types emerging from the fragments discussed corresponds roughly to particular historical circumstances. In the Middle Ages, most of the territory of modern Slovenia belonged to the Holy Roman Empire and, from the mid-fourteenth century, to the Inner Austrian Provinces. This may have been the main reason why South German types of neumatic notation, and later the type of Gothic notation described above, were normally used in this territory, similarly to South German regions and Austria. The notational picture presented gives the impression that, as far as music writing is concerned, political ties affecting every-day life exerted a stronger influence than ecclesiastical ones: ecclesiastically, during the Middle Ages, most Slovenian territories belonged to the Patriarchate of Aquileia (see below) in whose main centres square notation was used already from the second half of the thirteenth century onward. ${ }^{8}$ Notwithstanding, it seems that nonmonastic churches in the Slovenian lands employed manuscripts containing South German notational types. This relationship can be further observed in

8 Camilot-Oswald 1997. 
manuscripts featuring square notation that were in use in the Istrian towns Koper/Capodistria and Izola/Isola, situated in the Venetian part of the Patriarchate. ${ }^{9}$ Instead, the existence of fragments in square notation and in Cistercian notation in Slovenian libraries may be explained by the presence in the country of communities that belonged to monastic orders originating in the West which, in turn, used manuscripts in square notation. Furthermore, all known Carthusian and Franciscan chant manuscripts connected to Slovenian lands are compiled in square notation, and the only known Cistercian manuscript features instead Cistercian notation. ${ }^{10}$

With regard to the content of plainchant fragments, the number of Mass manuscripts almost equals that for the Divine Office (Table 3).

Table 3: Types of manuscripts.

\begin{tabular}{lr}
\hline Type of manuscript & No. of fragments \\
\hline Mass & 11 \\
Notated missal & 49 \\
Gradual & 13 \\
Sequentiary & 2 \\
Kyriale & 7 \\
Missal & \\
Divine Office & 14 \\
Notated breviary & 59 \\
Antiphoner & 5 \\
Psalter & 1 \\
Hymnal & \\
Other & 9 \\
$\quad$ Occasional mus. records & 1 \\
Glagolitic compendium & 44 \\
Unidentified & 215 \\
\hline Total: &
\end{tabular}

9 Snoj 2006.

10 For Carthusian, Franciscan, and Cistercian sources see respectively Šter 2013; Snoj 2013; Snoj 2008. 
It may be mentioned that the majority of plenarium manuscripts, i.e. seven notated missals and eleven notated breviaries, are written in adiastematic neumes, testifying for the gradual disappearance of this type of liturgical manuscripts in the late Middle Ages. In some cases, the book typology cannot be defined unambiguously because of the incompleteness of the fragments, e.g. a folio containing a sequence may be designated as a fragment of a sequentiary, but it could also have come from a gradual, etc. The contents, indeed, of a high number of fragments remain unidentified due to their small size or illegibility.

Another question that can be raised in connection with the fragments of plainchant manuscripts concerns how they have been preserved. Almost all of them survived as bookbinding material. There are, however, noteworthy exceptions, such as the parchment strips employed in an organ mechanism discovered during the restoration of the instrument, or parchment pieces used in the construction of a wooden altar in a village church, discovered during its replacement by a new one. ${ }^{11}$ These examples suggest that it was not only for bookbinding, but also for various other practical purposes that sheets from redundant manuscripts were employed; the majority of these purposes were of such a nature that the sheets disappeared for ever.

Since it is likely that the original manuscripts may have been dismembered at, or close to the moment when their parchment was used by bookbinders, the date of binding may cast light on the history of the manuscripts from which the fragments came from. The figures in Table 4 show the approximate numbers of books, manuscripts or archival documents that were bound at a particular moment of time using folios coming from plainchant manuscripts, revealing that it was most probably in the second half of the seventeenth and early eighteenth centuries that the majority of plainchant manuscripts fell victim to bookbinders' scissors. ${ }^{12}$

11 Respectively, no. 2.41 and no. 2.203 in Snoj 2018. Three fragments have been preserved as complete fascicles (nos. 2.113, 1.181, 2.182).

12 The figures refer to the number of bindings and are therefore higher than the number of fragments. They are approximate: in several cases, it was not possible to determine the time of binding. 
Table 4: Date and number of bindings containing fragments.

\begin{tabular}{rr}
\hline Time & No. of bindings \\
\hline-1500 & $\sim 23$ \\
$1500-1550$ & $\sim 11$ \\
$1550-1600$ & $\sim 17$ \\
$1600-1650$ & $\sim 70$ \\
$1650-1700$ & $\sim 183$ \\
$1700-1750$ & $\sim 66$ \\
$1750-$ & $\sim 4$ \\
\hline
\end{tabular}

Finally, it is possible to place the fragments of music manuscripts within the wider context of medieval book production. In order to gain a more precise idea about the proportion of music manuscripts among the fragmentary sources, a brief survey of the fragments in the National and University Library in Ljubljana is necessary here (Table 5).

Table 5: Fragments in the National and University Library in Ljubljana. ${ }^{13}$

\begin{tabular}{lr}
\hline Types of manuscripts & Number \\
\hline Liturgical manuscripts & $\sim 90$ \\
Other Latin & $\sim 88$ \\
Music manuscripts & 38 \\
Non-Latin manuscripts & $\sim 4$ \\
\hline
\end{tabular}

The bindings of the library's oldest holdings comprise approximately 220 fragments of destroyed medieval codices, the majority of which came from various liturgical manuscripts. It is also possible that a significant number of liturgical fragments survive among the group of unidentified Latin fragments (cf. 'Other Latin' in Table 5). Moreover, given that the contents of music manuscripts, with

13 Here, the term 'fragment' refers to what has been preserved in one binding, irrespective of whether the folios of the same codex appear in several bindings. The figures in the Table are approximate. They refer to what has been found in the bindings of books in ordinary location (excluding special collections) up to the shelfmark 22000 , which may be regarded as the oldest library collection. 
only few exceptions, may also be related to a liturgical use, it is possible to conclude that two thirds of the total number of destroyed codices, the remnants of which are kept in the said library, were liturgical manuscripts.

\section{Some notable examples}

A number of interesting fragments whose origin cannot be securely connected to Slovenian territories were also discovered. The National and University library preserves a fragment of a twelfth-century manuscript containing texts by Guido of Arezzo. On one of the two preserved folios, there is a section of Chapter XVII of Guido's Micrologus, in which he describes his method of automatic composition; that is, how a melody can be obtained from the succession of vowels in a given text. ${ }^{14}$ On the other folio, it is possible to read a section of Guido's Prologus in Antiphonarium. A close examination of the texts, and a comparison of their variant readings with fifty-five sources for the Micrologus and fifty sources for the Prologus on which the modern edition of these treatises is based, reveals that the version in the fragment is very close to that in a manuscript from the Benedictine abbey of St Ulrich and Afra in Augsburg (eleventh-twelfth century). ${ }^{15}$ However, the older Augsburg manuscript cannot have been used as an exemplar of the Ljubljana copy; the latter does not exactly match the former, but contains instead some variants that can be found in some other traditions of Guido's texts. It is, thus, possible that the scribe of the fragment copied the text by comparing two different versions, or that the Ljubljana fragment bears testimony to another, hitherto unknown, written tradition of Guido's texts. The fragment itself does not include any clue enabling a more precise definition of its place of origin.

Among the few surviving fragments containing polyphonic music, two are particularly noteworthy. In the Archiepiscopal Archives in Ljubljana, there are two incomplete bifolios written in Italian mensural notation (Fig. 3). ${ }^{16}$ So far, the pieces have not been identified, mostly due to the poor conservation conditions of the fragments which makes the script hard to read. It is likely, however, that the folios belonged to a copy of an unidentified theoretical treatise. One folio con-

14 SI-Ln, inv. 11/97, 1.

15 The manuscript is Wolfenbüttel, Herzog-August Bibliothek, Gud. Lat. 8,334. Van Waesberghe 1955; Van Waesberghe 1975.

16 SI-Lna, NŠAL 102, 75 (collection of various fragments, uncatalogued and so far without shelfmark). See Höfler 1966. 
tains psalmodic formulas written in square notation, while on the other the indications prima divisio and secunda divisio can be read in the right margin, possibly as explanations of the notated pieces.

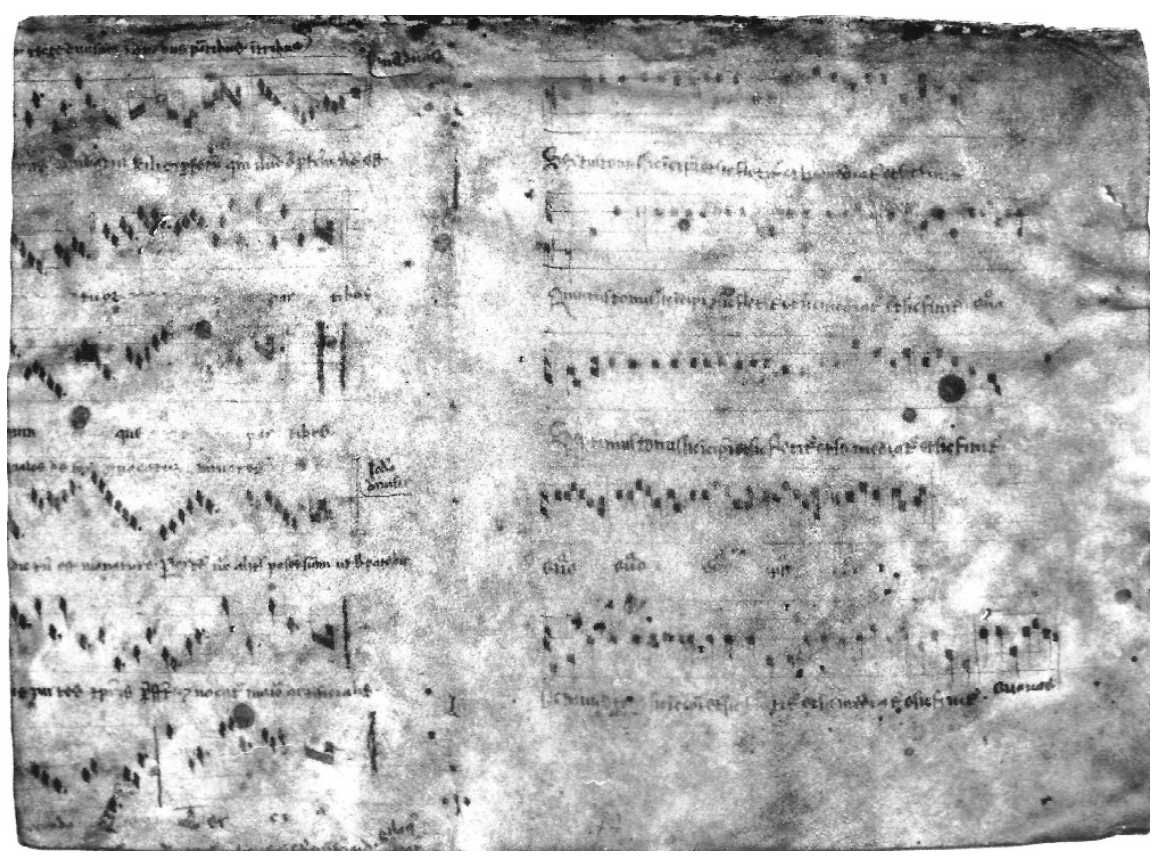

Fig. 3: SI-Lna, 102, 75 (Collection of Fragments); @ Ljubljana, Archiepiscopal Archives.

A unique example is a fragment consisting of two parchment folios both containing plainchant pieces with texts translated into Old Church Slavonic and written in Glagolitic script. ${ }^{17}$ On the first folio, there is the Genealogy according to Matthew and on the second, an unidentified and incomplete chant, followed by the Alleluia Laetamini in domino for the feasts of martyrs, and a Sanctus (Fig. 4). The original manuscript from which the folios came was probably some kind of plainchant 'compendium', rather than a more common gradual or antiphoner. It is likely that it was compiled and used at one of the Roman Church communities that were allowed to perform liturgy in the Slavonic language, such as those that existed in Croatia along the Adriatic coast.

17 SI-Ln, R, inv. n. S. f. 48/5. See Snoj 2017. 


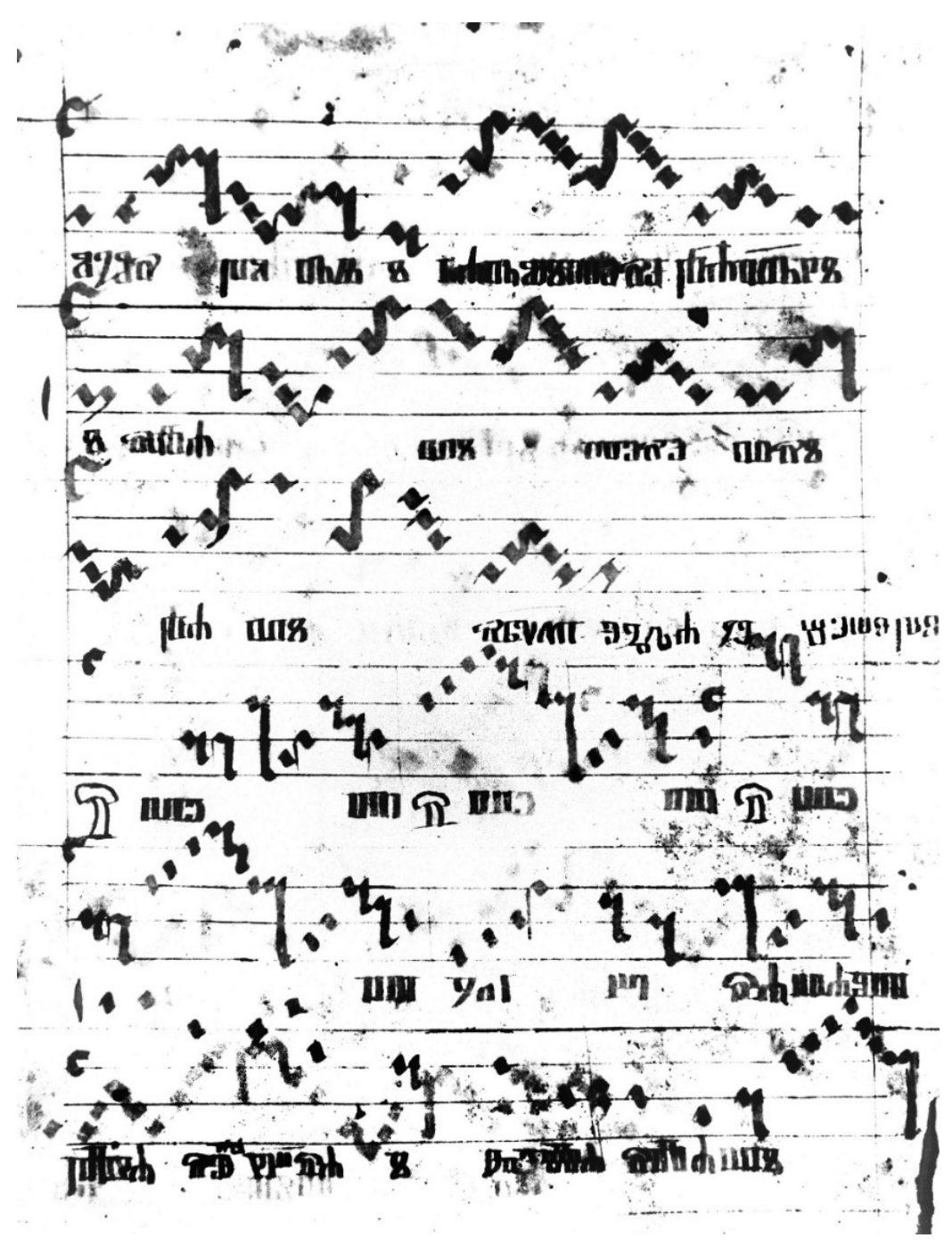

Fig. 4: SI-Ln, R, inv. n. S. f. 48/5; final portion of the All. Laetamini in domino, and beginning of the Sanctus; (C) Ljubljana, National and University Library.

The liturgy in Old Church Slavonic was also performed in the Emmaus Benedictine abbey in Prague, founded by Emperor Charles IV in 1346. Having witnessed the Slavonic liturgy in Croatia, the Emperor decided that the newly-founded abbey should perform it in Slavonic, too; thus, he purposely summoned monks from Croatia to Prague. The melodic variants of the pieces preserved in the frag- 
ment are, indeed, very close to those in Bohemian manuscripts of the fifteenth and sixteenth centuries. Furthermore, because the Gothic notation of the fragment discloses several Eastern characteristics such as the tendency to avoid virga, or the absence of the upside-down $\mathrm{U}$ shape in the torculus, whose melodic progression is rendered always by a succession of pes and clivis, the Glagolitic 'compendium' was probably produced somewhere in Central Europe rather than on the Adriatic coast. However, it is possible that the manuscript was not used by the monks of Emmaus, since the abbey was taken over by the Hussites already in 1419, whereas the script of the fragment appears to be of a later date.

So far, only one other similar fragment containing Western plainchant with texts in Old Church Slavonic written in the Glagolitic script has been found. However, the fragment, now held in Prague, cannot come from the same manuscript as the fragment kept in Ljubljana. ${ }^{18}$

Plainchant fragments, especially those dating to the late Middle Ages, may at first seem less interesting. However, since two identical plainchant manuscripts hardly existed in the Middle Ages, almost every fragment bears some features worthy of note, be it the presence of a rare saint's Office, a unique variant of an otherwise known Office, a special arrangement of chants, particular melodic variants not encountered in other sources, or certain peculiarities of the notation. In addition, it is only by collecting and comparing fragments that the possible extent of the medieval production of plainchant manuscripts may be surmised. And it is only in this way that the web of once existing plainchant manuscripts could be reconstructed as much as possible, leading up to a more accurate factual history of the spread, growth and development of liturgical chant in the Middle Ages.

\section{The question of provenance}

One of the main challenges in the study of surviving fragments in Slovenia is establishing where the original manuscripts might have been in use. The history of these manuscripts can, at least in part, be illuminated by exploring the ways in which their membra disiecta have been preserved. If a fragment consists of just one or two parchment folios, preserved in the binding of a book published abroad, it is reasonable to assume that either the fragment came to its present location together with the already bound book, or that the book was bound - or

18 Prague, Strahovská knihovna, inv. č. 290 / sign. Tres I - 7/m. See Eben 2017. 
re-bound - locally using discarded material from nearby libraries. There are many such cases. On the other hand, if a fragment consists of several folios, scattered in the bindings of printed volumes and archival documents that were produced somewhere in the Slovenian territory, it is more probable that the original manuscript was located somewhere in surrounding areas at the time of its destruction. One such example is a fragment of a psalter consisting of eight folios. ${ }^{19}$ Some of these survived in the archival documents of the Cistercian Abbey of Stična / Sittich, one in a register from a nearby parish church, and a few in the archival documents of Ljubljana, all dating to the 1630s. In other words, the psalter in question must have been somewhere in the vicinity of Ljubljana at the beginning of the 1630s, when it was dismembered and its folios used for various purposes, including as wrappers. If we apply this methodology to the entire extent of surviving fragments, only some forty plainchant manuscripts out of 215 may have been in Slovenian territories at the time of their destruction..$^{20}$

This number seems to correspond roughly to the needs of churches that existed in Slovenian territories during the Middle Ages. In that period, the territory that constitutes modern-day Slovenia was divided among different political entities: the Duchy of Carniola with its capital in Ljubljana/Laibach; the Duchy of Styria with its southern parts now being part of Slovenia; the Duchy of Carinthia with a small portion now belonging to Slovenia; the strip of land on the Adriatic coast formed instead part of the Republic of Venice, while some areas in the east belonged to the Hungarian Kingdom. From the point of view of ecclesiastical history, the regions south of the river Drava/Drau, including the Venetian strip at the Adriatic coast, belonged to the Patriarchate of Aquileia, while those to the north belonged to the Archdiocese of Salzburg; the areas under the Kingdom of Hungary, instead, formed part of the Hungarian ecclesiastical organisation. This vast territory was subdivided into several parishes, and included about fifty monasteries and several canon chapters. Apart from the Diocese of Koper/Capodistria, which was politically affiliated to Venice, there was no diocese in this territory until 1461, when Emperor Frederick III established a new diocese with a chapter of canons in the capital of Carniola (Ljubljana). ${ }^{21}$

The medieval history of the majority of these ecclesiastical institutions is obscure. With the exception of some major monasteries (Stična/Sittich, Žiče/Seitz, Kostanjevica/Landstrass), very few written records and manuscripts

19 No. 2.77 in Snoj 2018.

20 This is an approximate figure; in many cases, it is difficult to establish securely the time and place of the destruction.

21 Ambrožič 2010, 162-184, 188-191, 194-197. 
from Slovenian monasteries and chapters have survived to the present day. The difficulty in attributing particular fragments to particular churches is also due to there being hardly any specific knowledge concerning the liturgy performed in the churches across Slovenian territories, as well as to the incompleteness of the fragments. In addition, these only contain a small portion of the liturgy, which often does not show those peculiarities that would allow for a reasonable hypothesis about their origin. It is, in fact, only rarely that the place of use of a plainchant manuscript preserved only fragmentarily can be deduced with some degree of certainty.

One such example is the fifty-five folios scattered across the archives and libraries in Ljubljana that were written by the same easily recognizable hand (Fig. 5), and notated in the type of German 'Gothic-Messine' notation described above. These fragments, used in the bindings of various archival records from the second half of the seventeenth century up to the first decades of the eighteenth century, are the remnants of a two-volume antiphoner and of a psalter. ${ }^{22}$ Since one folio contains a segment of the versified Office of the Aquileian martyrs St Hellarus and St Tatianus, it is safe to assume that the antiphoner followed the Aquileian rite and must have therefore been in use somewhere in the Patriarchate. However, the place of use must have been within the Imperial, Austrian part of the Patriarchate rather than the Venetian one, where manuscripts were instead ordinarily written in square notation. The charter of the then newlyfounded Diocese of Ljubljana (1461) contains an instruction for the chapter of the diocese to perform the liturgy in accordance with the Aquileian rite. Furthermore, it is known that the Diocese of Ljubljana replaced the Aquileian rite with the Roman liturgy after the second half of the seventeenth century. It is, therefore, reasonable to assume that the antiphoner and the psalter in question were compiled for the new diocese chapter and that they were then abandoned some time after 1650, that is, in the period when the archival documents containing their folios came into being..$^{23}$

The fact that there are remnants of more than 200 plainchant manuscripts in Slovenia, many of them consisting of just one folio, leads to the assumption that the leaves of the original manuscripts may have been scattered across larger areas, and that their other remnants could have been preserved in neighbouring regions. The largest and most relevant collection of music fragments for the study of Slovenian fragments is now in the National Library in Vienna; its online catalogue includes at present 675 items from different periods, written in various

22 Ns. 2.127-2.129 in Snoj 2018.

23 There is scarcely any other fragment for which a similar assumption could be made. 
types of notation. ${ }^{24}$ By browsing through the Viennese collection it is possible to observe close similarities with the scribal hands of the Slovenian fragments. Yet, upon a detailed examination of the scripts, it was only in a couple of cases that the same hand was recognised with a considerable degree of certainty. Let us take as an example the thirty fragments in German adiastematic neumes that were found in Slovenian libraries. Of the 306 fragments written in adiastematic neumes in the Viennese collection, the great majority contain German adiastematic neumes. However, individual comparisons of the Slovenian fragments with any of the Viennese ones showed only three or four cases where a more convincing correspondence could be established. ${ }^{25}$

It is clear from this presentation that medieval plainchant manuscript production in Central European regions must have been very intensive. However, the actual number of compiled manuscripts still remains a matter of speculation. In order to gain a more precise idea of the extent of the Central European production, which includes also what has been preserved in modern Slovenia, all the existing fragments scattered across European libraries should be collected and put in one large database to enable various comparisons. The study of individual fragments or smaller collections of fragments is certainly necessary and unavoidable, yet without broader considerations it cannot lead to reliable results.

24 Musikalische Quellen des Mittelalters in der ÖNB; the head of the project: Alexander Rausch, researchers: Robert Klugseder, Ana Čizmić, Eva Veselovská, Hanna Zühlke, etc. $<$ http://www.cantusplanus.at/de-at/> (accessed July 2020).

25 The fragment in the binding of SI-Ln, 11963 might come from the same manuscript as Vienna, Österreichische Nationalbibliothek, Cod. 1248; the notation (but not the text) of the fragment SILz, LJU/0338, Maculatures II (3), Folder 24 appears to be the work of the same notator as Vienna, Österreichische Nationalbibliothek, Cod. 1797; the fragment in the binding of one of the birth registers from Limbuš (Limbuš, r. 1624-1646, now in the Archiepiscopal Archives of Maribor) seems very similar to Vienna, Österreichische Nationalbibliothek, Cod. 2212; the notation of the adiastematic fragment kept in the Franciscan Monastery Kamnik (without shelfmark) is very close to Vienna, Österreichische Nationalbibliothek, Cod. 3081. 


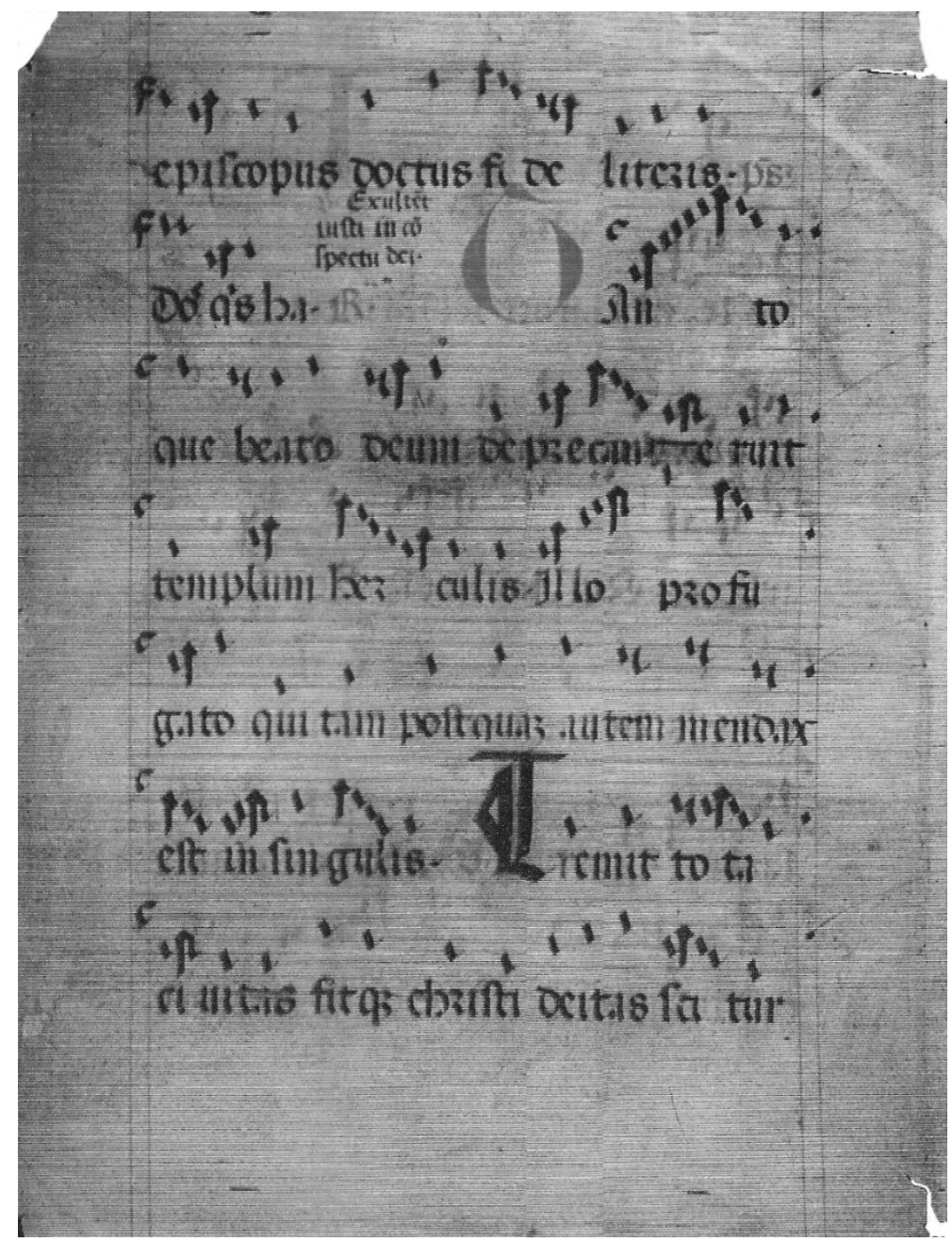

Fig. 5: SI-Lz, LJU/0338, Maculatures II (3), Folder 22; from the versified Office of St Hellarus and Tatianus; @ Ljubljana, Historical Archives. 


\section{References}

Ambrožič, Matjaž (2010), Prvih 1000 let krščanstva na Slovenskem [The First Millenium of Christianity in Slovenia], Ljubljana: Teološka fakulteta.

Brownrigg, Linda L., and Margaret M. Smith (eds) (2000), Interpreting and Collecting Fragments of Medieval Books. Proceedings of The Seminar in the History of the Book to 1500, Los Altos Hills, CA and London: Anderson-Lovelace and The Red Gull Press.

Brunius, Jan (2005), 'Medieval manuscript fragments in the National Archives - a survey', in Jan Brunius (ed.) Medieval book fragments in Sweden, Stockholm: Kungliga Vitterhets historie och antikvitets adademien, 9-17.

Camilot-Oswald, Raffaella (1997), Die liturgischen Musikhandschriften aus dem mittelalterlichen Patriarchat Aquileia (Monumenta Monodica Medii Aevi, Subsidia 2, Teilband 1), Kassel: Bärenreiter.

Eben, David (2017), 'Strahovské hlaholské zlomky a jejich vztach k pražské chorální tradici', in Kubinová et al. (eds), 55-65.

Hiley, David (ed.) (2004), Die Erschliessung der Quellen des mittelalterlichen liturgischen Gesangs (Wolfenbütteler Mittelalter-Studien 18), Wiesbaden: Harrassowitz.

Hiley, David, and Janka Szendrei (2001), 'Notation: History of Western notation, Plainchant', in Grove Music Online, <doi.org/10.1093/gmo/9781561592630.article.20114〉.

Höfler, Janez (2006), 'Menzuralni fragment iz nadškofijskega arhiva v Ljubljani’, in Muzikološki zbornik / Musicological Annual, 2: 12-17.

Kubinová Kateřina, et al. (eds) (2017), Karel IV. a Emauzy. Liturgie - text - obraz, Prague: Artefactum.

Medieval Manuscripts and Parchment Fragments from Finland, <https://pro.europeana.eu/ data/medieval-manuscripts-and-parchment-fragments-from-finland $\rangle$.

Musikalische Quellen des Mittelalters in der ÖNB, 〈http://www.cantusplanus.at/de-at〉. Slovakian Early Music Database, <http://cantus.sk>.

Snoj, Jurij (2006), 'The Plainchant Manuscripts from Koper/Capodistria', in László Dobszay (ed.), Cantus Planus. Papers Read at the $12^{\text {th }}$ Meeting of the IMS Study Group Cantus Planus, Budapest: Institute for Musicology of the Hungarian Academy of Sciences, 489-502.

Snoj, Jurij (2018), Gregorijanski koral v srednjeveških rokopisih na Slovenskem [Plainchant in Medieval Manuscripts in Slovenia], Ljubljana: Založba ZRC.

Snoj, Jurij (2013), 'The Franciscans in Carniola and their Chant', in Barbara Haggh-Huglo and Debra Lacoste (eds), Cantus Planus. Papers Read at the $15^{\text {th }}$ Meeting of the IMS Study Group Cantus Planus, Lions Bay: The Institute of Mediaeval Music, II, 597-617.

Snoj, Jurij (2008), 'The Gradual of Stična / Sittich', in David Hiley and Gábor Kiss (eds), 'Dies est leticie'. Essays on Chant in Honour of Janka Szendrei, Ottawa: The Institute of Mediaeval Music, 463-483.

Snoj, Jurij (2017), 'Nově objevený zlomek rukopisu hlaholského chorálu’, in Kubinová, et al. (eds), 67-75.

Stäblein, Bruno (1975), Schriftbild der einstimmigen Musik (Musikgeschichte in Bildern III/4), Leipzig: VEB Deutscher Verlag für Musik.

Szendrei, Janka (2002), 'Source research in Hungary after 1970', in Mauro Perani and Cesarino Ruini (eds), Fragmenta ne pereant. Recupero e studio dei frammenti di manoscritti medievali e rinascimentali riutilizzati in legature, Ravenna: Angelo Longo Editore, 141-155. 
Šter, Katarina (2013), Srednjeveški koral v kartuziji Žiče [Plainchant in Charterhouse Žiče (Seitz)], 〈https://mi.zrc-sazu.si/en/publikacije/srednjeveski-koral-v-kartuziji-zice-1\#v〉 (accessed July 2020), Ljubljana: Založba ZRC SAZU.

Van Waesberghe, Joseph Smits (ed.) (1955), Guidonis Aretini Micrologus (Corpus scriptorum de musica 4), Rome: American Institute of Musicology.

Van Waesberghe, Joseph Smits (ed.) (1975), Guidonis Prologus in Antiphonarium (Divitiae musicae artis A III), Buren: F. Knauf.

Veselovská, Eva (2002), Mittelalterliche liturgische Kodizes mit Notation in den Archivbeständen von Bratislava, I, Bratislava: Slowakisches Nationalmuseum - Musikmuseum.

Veselovská, Eva (2006), Mittelalterliche liturgische Kodizes mit Notation in den Archivbeständen von Bratislava, II, Bratislava: Institut für Musikwissenschaft der Slowakischen Akademie der Wissenschaften. 
